\title{
P. Scarron, Théâtre complet
}

\section{Chiara Rolla}

\section{OpenEdition}

\section{Journals}

\section{Edizione digitale}

URL: http://journals.openedition.org/studifrancesi/7907

DOI: $10.4000 /$ studifrancesi.7907

ISSN: 2421-5856

\section{Editore}

Rosenberg \& Sellier

\section{Edizione cartacea}

Data di pubblicazione: 1 juillet 2009

Paginazione: 390

ISSN: 0039-2944

\section{Notizia bibliografica digitale}

Chiara Rolla, «P. Scarron, Théâtre complet», Studi Francesi [Online], 158 (LIII | II) | 2009, online dal 30

novembre 2015, consultato il 13 janvier 2021. URL: http://journals.openedition.org/studifrancesi/7907 ; DOI: https://doi.org/10.4000/studifrancesi.7907

Questo documento è stato generato automaticamente il 13 janvier 2021.

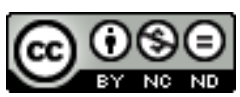

Studi Francesi è distribuita con Licenza Creative Commons Attribuzione - Non commerciale - Non opere derivate 4.0 Internazionale. 


\section{P. Scarron, Théâtre complet}

\section{Chiara Rolla}

\section{NOTIZIA}

P. SCARRON, Théâtre complet, éd. critique avec introduction, notes et glossaire par Barbara somмоvigo, Felici ed., 2007, pp. 980.

1 Malgrado ci risulti essere di imminente pubblicazione (ottobre 2008) un'edizione critica del teatro completo di Scarron a cura di Véronique Sternberg per le edizioni Champion, segnaliamo l'interessante e analogo volume, pubblicato nel 2007, curato da Barbara Sommovigo. Si tratta di un lavoro ricco e ben documentato che colma una lacuna rimasta tale dal 1775. Nell'Introduzione l'A. ripercorre le tappe fondamentali della produzione teatrale di Scarron, mettendone in evidenza le fonti - il teatro di Corneille e la comedia spagnola - le caratteristiche proprie - rottura con alcuni meccanismi tradizionali, presenza del burlesque - e l'influsso che essa ha avuto anche su autori del calibro di Molière. I testi riprodotti sono quelli originali, anche se l'A. dichiara aver consultato tutte le edizioni successive, fino alle più recenti, che vengono puntualmente citate nella notice che precede ogni pièce. Il volume comprende anche una schematica biografia del poliedrico autore seicentesco, la ricostruzione della cronologia delle opere e un interessante ed utile glossario che fa riferimento ai principali dizionari dell'epoca e moderni. 